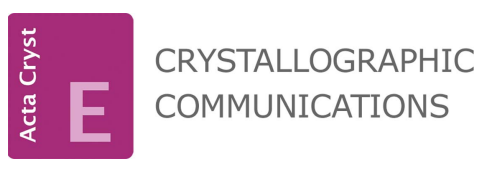

ISSN 2056-9890

Received 23 June 2021

Accepted 7 September 2021

Edited by A. M. Chippindale, University of Reading, England

Keywords: cyanurate anion; five-coordinate $\mathrm{Li}^{+}$ cation; four-coordinate $\mathrm{Li}^{+}$cation; bridging aqua ligand; supramolecular assembly; hydrogenbonding motifs; band gap; thermogravimetric analysis; crystal structure.

CCDC reference: 1991191

Supporting information: this article has supporting information at journals.iucr.org/e
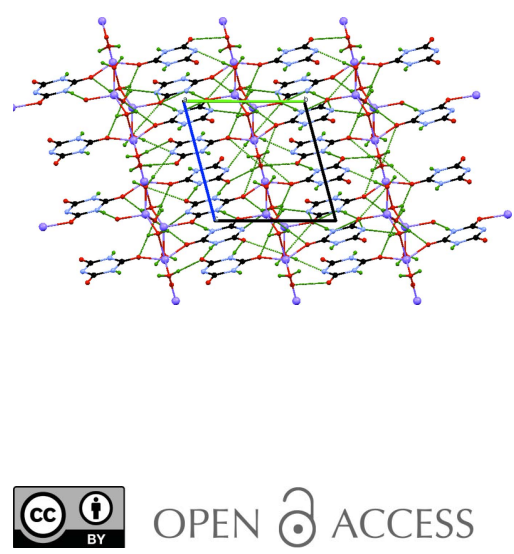

\section{Polymeric coordination complex of lithium(I) with aqua and cyanurate ligands}

\author{
Anjapuli Ponnuvel, ${ }^{a}$ Arumugam Pillai Kala, ${ }^{\text {a }}$ Karachalacherevu Seetharamiah \\ Nagaraja ${ }^{b}$ and Chandran Karnan ${ }^{\mathrm{c} *}$
}

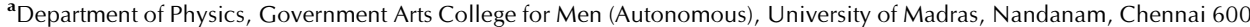
035, India, 'bepartment of Chemistry, Dr. M.G.R. Educational and Research Institute, Chennai 600 095, India, and ${ }^{\mathrm{c}}$ Department of Physics, Dr. M.G.R. Educational and Research Institute, Chennai 600 095, India. *Correspondence e-mail: c.karnan@yahoo.com

The polymeric title complex, poly[hexa- $\mu$-aqua-diaquatetra- $\mu$-cyanurato-tetralithium] $\left[\mathrm{Li}_{4}\left(\mathrm{C}_{3} \mathrm{H}_{2} \mathrm{~N}_{3} \mathrm{O}_{3}\right)_{4}\left(\mathrm{H}_{2} \mathrm{O}\right)_{7}\right]_{n}$, synthesized at room temperature from an aqueous solution of lithium hydroxide and cyanuric chloride, crystallizes in the triclinic space group $P \overline{1}$. There are two distinct $\mathrm{Li}^{+}$cations in the asymmetric unit, one of which, Li1, has distorted trigonal-bipyramidal geometry and is coordinated via oxygen to two cyanurate anions occupying equatorial positions, and three water molecules, two in the axial positions and the third in an equatorial position. One of the axial water ligands and the equatorial water ligand are involved in bridging to a crystallographically equivalent Li1 cation. A centre of inversion lies between the two Li1 cations and the Li1 . . Li1 distance is 3.037 (5) $\AA$. The remaining axial water ligand bridges to the second Li cation, Li2, which is disordered over two crystallographic sites with approximately equal occupancy, and has an Li1 …Li2 distance of 3.438 (7) $\AA$. The terminal Li2 cation is coordinated to three water molecules and an oxygen atom from a cyanuric anion and has a distorted tetrahedral geometry. A three-dimensional network of intermolecular hydrogen bonds involving $\mathrm{N}-\mathrm{H} \cdots \mathrm{O}, \mathrm{O}-\mathrm{H} \cdots \mathrm{O}$ and $\mathrm{O}-\mathrm{H} \cdots \mathrm{N}$ interactions serves to hold the structure together. The title compound was further characterized using IR and UV-vis spectroscopy and TG-DTA analysis.

\section{Chemical context}

A number of physical and structural properties, including molecular geometry, metal-ligand bonding and directional supramolecular architecture, control and influence the applications of hybrid metallo-organic coordination compounds (Coubrough et al., 2019). Such compounds find potential applications in catalysis, gas storage, ion exchange, magnetic materials, sensors, optics and batteries (Qu et al., 2016). The various possible metal and linker combinations are endless and have led to the synthesis of thousands of new materials with different metal geometries and functionalities (Chatenever et al., 2019). Among the metals investigated, lithiumbased complexes have unique advantages, exploiting properties of the lithium cation such as small ionic radius, high polarizing power, aqueous solubility and low economic cost (Ge et al., 2018; Wan et al., 2012). In solution, the lithium cation is of great importance because it can bind with selective organic ligands, leading to uses in many areas, including as active cellular components in ion-selective electrodes (ISE) in medicine, in nuclear power and in batteries (Ivanova et al., 2019). 
<smiles>O=c1[nH]c(=O)[nH]c(=O)[nH]1</smiles>

(I)<smiles>Oc1nc(O)nc(O)n1</smiles>

(II)<smiles>O=c1nc(O)[nH]c(=O)[nH]1</smiles>

(III)

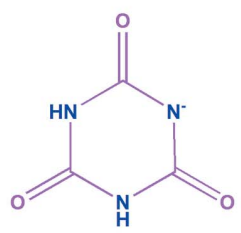

(IV)

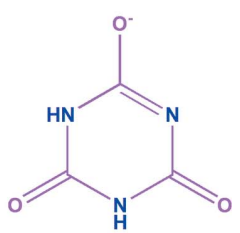

(V)
Figure 1

Tautomerism of cyanuric acid showing the trione (I) and triol (II) forms together with the resonance structures of the cyanurate anion [(III), (IV) and $(\mathrm{V})]$.

Cyanuric acid (1,3,5-triazine-2,4,6-triol) is an industrially important compound used to make pesticides, dyes, and disinfectants (Cho et al., 2014). The acid is used as a chlorine stabilizer for outdoor swimming pools and sizeable industrial water systems. It is non-toxic to human and aquatic animals. It also has the remarkable property of biodegradability by soil bacteria (Prabhaharan et al., 2015) and was recently found to be an effective nucleating agent during kinetic studies of biodegradable poly(L-lactide) and poly(3-hydroxylbutyrate) co-polyesters (Pan et al., 2013; Weng \& Qiu, 2014).

With regard to metallo-organic chemistry, cyanuric acid is an important ligand due to its structural symmetry based on a planar six-membered ring, the existence of canonical structures and the presence of multiple hydrogen-bond-donor centres (Divya et al., 2017). In its neutral, undissociated form, cyanuric acid shows tautomerism and can exist in the keto (I) or enol (II) forms (Fig. 1) (Abu-Salem et al., 2017). In basic solution, it forms an anion with resonance between the (III), (IV) and (V) forms (Fig. 1).

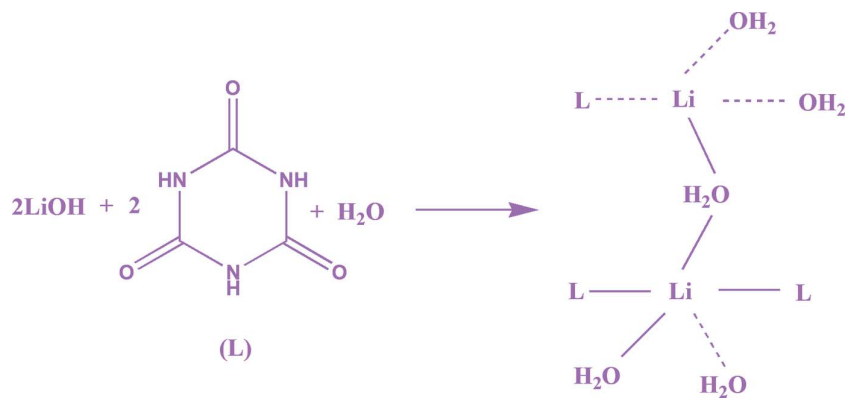

As cyanuric acid has three hydrogen-bonding-donor amine sites and three hydrogen-bonding-acceptor keto sites, it has been the subject of several structural and crystal-design studies (Shemchuk et al., 2017). In the present work, we report the synthesis of a new lithium complex of cyanuric acid, $\left[\mathrm{Li}_{4}\left(\mathrm{C}_{3} \mathrm{H}_{2} \mathrm{~N}_{3} \mathrm{O}_{3}\right)_{4}\left(\mathrm{H}_{2} \mathrm{O}\right)_{7}\right]_{n}$. The complex has been character-

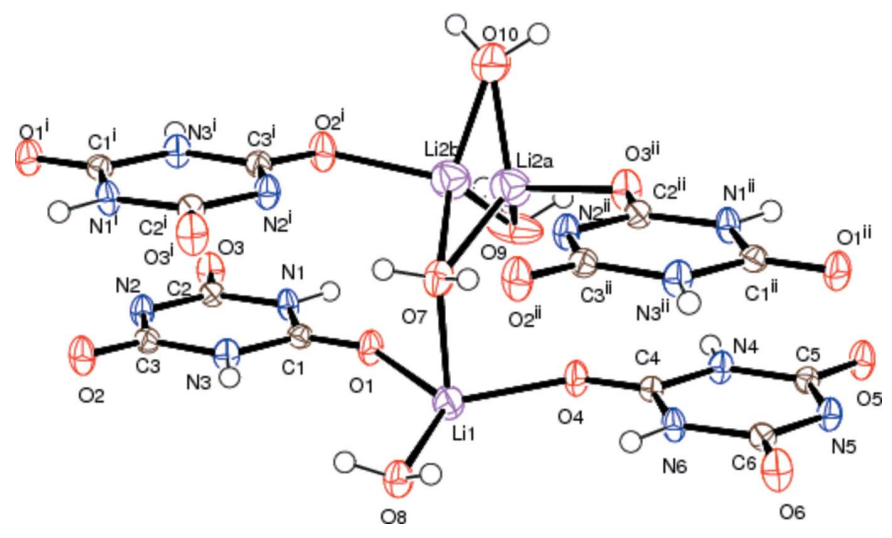

Figure 2

Coordination environments of the $\mathrm{Li}^{+}$ions in the title compound with the displacement ellipsoids shown at the $50 \%$ probability level. Li2 is disordered over two sites, $\mathrm{Li} 2 A$ and $\mathrm{Li} 2 B$, of approximately equal occupancy. [Symmetry codes: (i) $-x+2,-y+1,-z+1$; (ii) $-x, y+1, z$.]

ized by single-crystal X-ray diffraction, FTIR and UV-Vis spectroscopy, and TG-DTA analysis.

\section{Structural commentary}

The title compound crystallizes in the triclinic space group $P \overline{\mathbf{1}}$. The asymmetric unit comprises two lithium ions, two cyanurate ligands and three and a half coordinated water molecules. An inversion centre lies between the related $\mathrm{Li}^{+}$ cations, $\mathrm{Li} 1$ and $\mathrm{Li}^{\mathrm{i}}{ }^{\mathrm{i}}$, generating a molecular unit of formula $\left[\mathrm{Li}_{4}\left(\mathrm{C}_{3} \mathrm{H}_{2} \mathrm{~N}_{3} \mathrm{O}_{3}\right)_{4}\left(\mathrm{H}_{2} \mathrm{O}\right)_{7}\right]$ (Fig. 2).

The two crystallographically distinct cyanurate ligands exist in resonance form (IV) (Fig. 1), in which the negative charge is located on a nitrogen atom. Interestingly, for both ligands, coordination to lithium does not involve the deprotonated N2 and $\mathrm{N} 5$ atoms, but occurs via the keto oxygen atoms opposite (O1 and O4). This coordination preference may be due to the hard acid, $\mathrm{Li}^{+}$, preferring to bond to the harder base i.e. oxygen.

The $\mathrm{C}=\mathrm{O}$ groups involved in coordination to Li1, namely $\mathrm{C} 1=\mathrm{O} 1$ and $\mathrm{C} 4=\mathrm{O} 4$ have bond lengths of 1.2207 (19) and 1.2242 (19) A, respectively (Fig. 3), which are similar values to

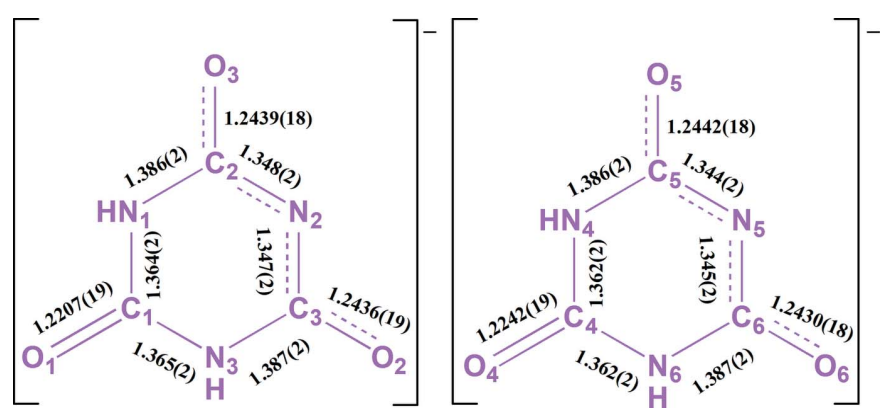

Figure 3

Observed bond lengths in the cyanurate anions found in the title compound. The delocalization of the negative charge on the deprotonated nitrogen atoms (N2 and N5) over the adjacent keto groups is shown as dashed lines. 
Table 1

Hydrogen-bond geometry $\left(\AA,^{\circ}\right)$.

\begin{tabular}{lllll}
\hline$D-\mathrm{H} \cdots A$ & $D-\mathrm{H}$ & $\mathrm{H} \cdots A$ & $D \cdots A$ & $D-\mathrm{H} \cdots A$ \\
\hline $\mathrm{N} 1-\mathrm{H} 1 \cdots \mathrm{O} 3^{\mathrm{i}}$ & 0.86 & 1.95 & $2.8054(17)$ & 175 \\
$\mathrm{~N} 3-\mathrm{H} 3 \cdots 5^{\mathrm{ii}}$ & 0.86 & 1.94 & $2.7964(16)$ & 173 \\
$\mathrm{~N} 4-\mathrm{H} 4 \cdots 2^{\mathrm{iii}}$ & 0.86 & 1.95 & $2.8033(17)$ & 175 \\
$\mathrm{~N}^{\mathrm{iii}}-\mathrm{H} 6 \cdots 6^{\text {iv }}$ & 0.86 & 1.95 & $2.8002(17)$ & 172 \\
$\mathrm{O} 8-\mathrm{H} 8 A \cdots \mathrm{O}^{\mathrm{iv}}$ & $0.86(2)$ & $1.92(2)$ & $2.7412(16)$ & $159(2)$ \\
$\mathrm{O} 8-\mathrm{H} 8 B \cdots \mathrm{O}^{\text {ii }}$ & $0.86(2)$ & $1.92(2)$ & $2.7443(16)$ & $160(2)$ \\
$\mathrm{O} 10-\mathrm{H} 10 A \cdots \mathrm{N}^{\mathrm{v}}$ & $0.87(2)$ & $2.16(2)$ & $3.0311(19)$ & $177(3)$ \\
$\mathrm{O} 10-\mathrm{H} 10 B \cdots \mathrm{N}^{\mathrm{vi}}$ & $0.86(2)$ & $2.18(2)$ & $3.0342(19)$ & $174(3)$ \\
$\mathrm{O} 7-\mathrm{H} 7 A \cdots 2^{\mathrm{vii}}$ & $0.88(3)$ & $2.09(3)$ & $2.908(2)$ & $154(2)$ \\
$\mathrm{O} 7-\mathrm{H} 7 B \cdots \mathrm{N} 2^{\mathrm{viii}}$ & $0.88(2)$ & $2.09(2)$ & $2.905(2)$ & $153(2)$ \\
\hline
\end{tabular}

Symmetry codes: (i) $-x+1,-y,-z+2$; (ii) $x+1, y-1, z$; (iii) $x-1, y+1, z$; (iv) $-x+2,-y+2,-z+1$; (v) $-x+1,-y+2,-z+2$; (vi) $x, y-1, z+1$; (vii) $x, y+1, z$; (viii) $-x+2,-y,-z+2$.

those found in related complexes (Divya et al., 2020). The remaining two $\mathrm{C}=\mathrm{O}$ groups in each ligand are involved in resonance and intermolecular hydrogen bonding (and, in the cases of $\mathrm{C} 2=\mathrm{O} 3$ and $\mathrm{C} 3=\mathrm{O} 2$, in bonding to $\mathrm{Li} 2 A$ and $\mathrm{Li} 2 B$ ) and have slightly longer bond lengths: $\mathrm{C} 2-\mathrm{O} 3,1.2439$ (18) $\AA$;

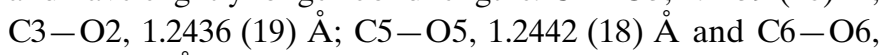
1.2430 (18) A. The delocalization of the negative charge on the deprotonated nitrogen atoms (N2 and N5) over the adjacent keto groups is shown as dashed lines in Fig. 2.

There are two distinct $\mathrm{Li}^{+}$cations in the asymmetric unit (Fig. 3). Li1 has a distorted trigonal-bipyramidal geometry and is coordinated via $\mathrm{O} 1$ and $\mathrm{O} 4$ to the two cyanurate anions, which occupy equatorial positions, and three water molecules, two $\left(\mathrm{H}_{2} \mathrm{O} 7\right.$ and $\left.\mathrm{H}_{2} \mathrm{O}^{\mathrm{i}}\right)$ in the axial positions and the third $\left(\mathrm{H}_{2} \mathrm{O} 8\right)$ in an equatorial position. The $\mathrm{Li1}-\mathrm{O}$ bond lengths lie in the range 2.012 (3)- 2.201 (3) $\AA$ and the bond angles of $\mathrm{O} 4-\mathrm{Li} 1-\mathrm{O} 1=118.40(13)^{\circ}, \mathrm{O} 4-\mathrm{Li} 1-\mathrm{O} 8=120.78(14)^{\circ}$, $\mathrm{O} 1-\mathrm{Li} 1-\mathrm{O} 8=120.74(14)^{\circ}$ and $\mathrm{O} 8^{\mathrm{i}}-\mathrm{Li} 1-\mathrm{O} 7=178.56(15)^{\circ}$ confirm the trigonal-bipyramidal Li1 coordination geometry. One of the axial water ligands, $\mathrm{H}_{2} \mathrm{O} 8^{\mathrm{i}}$, and the equatorial water ligand, $\mathrm{H}_{2} \mathrm{O} 7$, bridge to a crystallographically equivalent Li1 cation. The Li1 $\cdots \mathrm{Li}^{\mathrm{i}}{ }^{\mathrm{d}}$ distance is $3.037(5) \AA$, which is larger than the $\mathrm{Li}-\mathrm{Li}$ bond distance found in lithium metal.

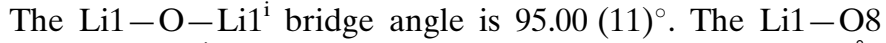
and Li1 $-\mathrm{O}^{\mathrm{i}}$ bond lengths are 2.032 (3) and 2.086 (3) $\AA$, respectively.

The remaining axial water ligand, $\mathrm{H}_{2} \mathrm{O} 7$, bridges to the second $\mathrm{Li}^{+}$cation, $\mathrm{Li} 2$, which is disordered over two sites, $\mathrm{Li} 2 A$ and $\mathrm{Li} 2 B$, which have approximately equal occupancies. The $\mathrm{Li} 1 \cdots \operatorname{Li} 2 A$ and $\operatorname{Li} 1 \cdots \operatorname{Li} 2 B$ distances are $3.438(7)$ and 3.439 (7) $\AA$, respectively. Li2 is coordinated to two more water molecules, $\mathrm{H}_{2} \mathrm{O} 9, \mathrm{H}_{2} \mathrm{O} 10$ and an oxygen atom from a cyanurate ligand (either $\mathrm{O}_{3}{ }^{\mathrm{ii}}$ for $\mathrm{Li} 2 A$ or $\mathrm{O} 2{ }^{\mathrm{iii}}$ for $\mathrm{Li} 2 B$ ) to complete its distorted tetrahedral coordination geometry. The $\mathrm{Li} 2-\mathrm{O}$ bond lengths lie in the range 1.931 (7)-2.057 (7) $\AA$ and the $\mathrm{O}-\mathrm{Li} 2-\mathrm{O}$ angles in the range $97.9(3)-125.3(3)^{\circ}$

\section{Supramolecular features}

Strong intermolecular hydrogen-bonding interactions (Table 1) link the individual $\left[\mathrm{Li}_{4}\left(\mathrm{C}_{3} \mathrm{H}_{2} \mathrm{~N}_{3} \mathrm{O}_{3}\right)_{4}\left(\mathrm{H}_{2} \mathrm{O}\right)_{7}\right]$ units into a three-dimensional network (Fig. 4). These involve interactions between water molecule $\mathrm{H}_{2} \mathrm{O} 8$ and the adjacent cyanurate anions [O8 $\cdots \mathrm{O}^{\mathrm{iv}}, \mathrm{O} 8 \cdots \mathrm{O} 5^{\mathrm{ii}}$ at $2.7412(16)$ and 2.7443 (16) А̊, respectively].

In addition, each cyanurate moiety forms two strong hydrogen bonds between the $\mathrm{N}-\mathrm{H}$ groups and oxygen atoms of adjacent molecules with $\mathrm{N}$...O distances in the range 2.7964 (16)-2.8054 (17) $\AA \quad\left(\mathrm{N} 1-\mathrm{H} 1 \cdots \mathrm{O} 3^{\mathrm{i}}, \quad \mathrm{N} 3-\mathrm{H} 3 \cdots \mathrm{O} 5^{\mathrm{ii}}\right.$, $\mathrm{N} 4-\mathrm{H} 4 \cdots \mathrm{O} 6^{\mathrm{iii}}$ and $\left.\mathrm{N} 6-\mathrm{H} 6 \cdots \mathrm{O} 6^{\mathrm{iv}}\right)$. Weaker hydrogenbonding interactions, with $\mathrm{N}$... $\mathrm{O}$ distances in the range 2.905 (2)-3.0342 (19) $\AA$ are also observed between the unprotonated $\mathrm{N}$ atoms of the cyanurate ions and nearby water molecules $\left(\mathrm{O} 7 \cdots \mathrm{N} 2^{\mathrm{vii}}\right.$, $\mathrm{O} 7 \cdots \mathrm{N} 2^{\text {viii }}$ and $\mathrm{O} 10 \cdots \mathrm{N} 5^{\mathrm{v}}$, $\left.\mathrm{O} 10 \cdots \mathrm{N} 5^{\mathrm{vi}}\right)$.

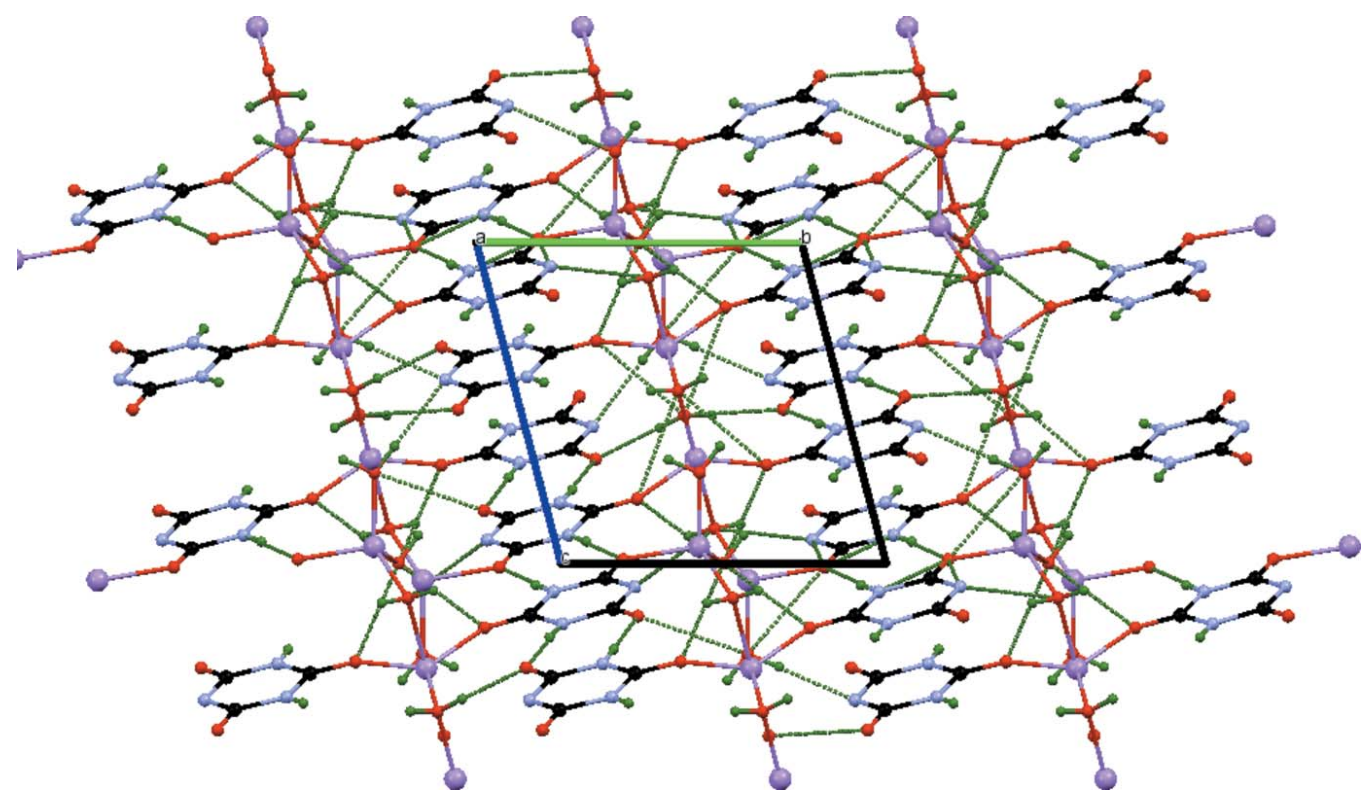

Figure 4

View of the crystal packing of the title compound along the $a$ axis. Hydrogen-bonding interactions are indicated by green dashed lines. 


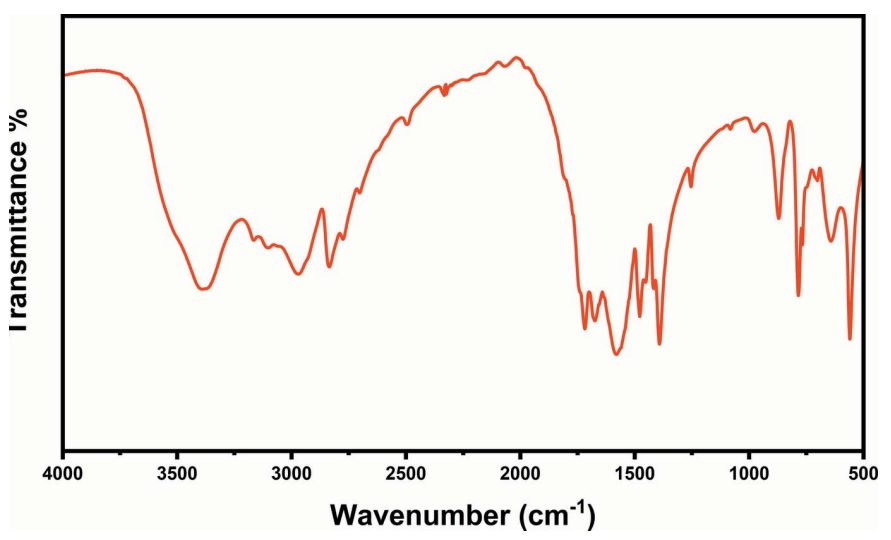

Figure 5

The infrared spectrum of the title compound.

Overall a supramolecular hydrogen-bonded assembly is formed, as seen previously in other systems (Suguna et al., 2014; Jeseentharani et al., 2010).

\section{Database survey}

A survey of the Cambridge Structural Database (CSD version 5.42, May 2021 update; Groom et al., 2016) revealed three polymeric metal complexes containing ligands related to the cyanurate ligand. These are $\left(\mu_{2}-4,4^{\prime}\right.$-bipyridine $)$ bis[4,6-dihydroxy-1,3,5-triazin-2(1H)-olato]dicopper(I) (WICCIV; Yue et al., 2006) and catena-[bis( $\mu$-4,6-dioxo-1,4,5,6-tetrahydro-1,3,5triazin-2-olato)tetraaquastrontium(II)] (QEHKOG; Divya et $a l ., 2017)$, both of which crystallize in the monoclinic crystal system, together with catena-[tetrakis $(\mu-2,4,6$-trioxo-1,3,5triazinan-1-ide)bis( $\mu$-aqua)tetraaquacopper(II)disodium(I)] (KUXFAK02; Divya et al., 2020), which, like the title compound, crystallizes in the triclinic space group $P_{\overline{1}}$.

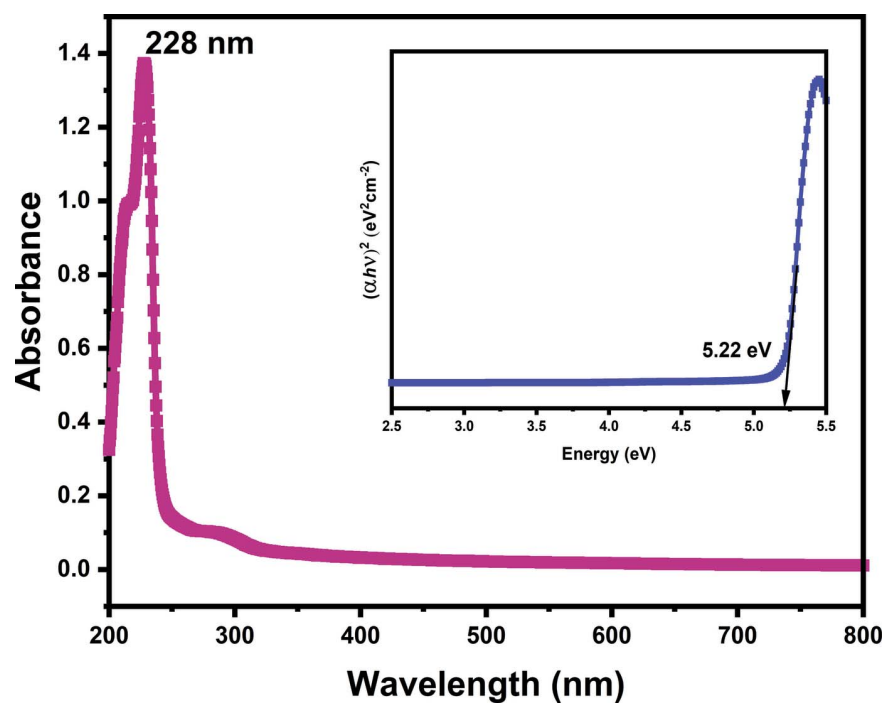

Figure 6

The absorption spectrum of the title compound. The direct bandgap, $E_{\mathrm{g}}$, is estimated from the plot in the inset to be $5.22 \mathrm{eV}$.

\section{Fourier transform infrared spectroscopy}

The FTIR spectrum of the title compound was measured using a Perkin Elmer Spectrum One instrument over a 450$4000 \mathrm{~cm}^{-1}$ scan range at $1.0 \mathrm{~cm}^{-1}$ resolution (Fig. 5). The bands at $3400(s h, m)$ and $3389 \mathrm{~cm}^{-1}(b r)$ correspond to $v(\mathrm{O}-$ H) (Prabhaharan et al., 2015; Bourzami et al., 2018) and those at 3165,3102 and $2831 \mathrm{~cm}^{-1}$ to $v(\mathrm{~N}-\mathrm{H}$ ) (Divya et al., 2020; Surinwong et al., 2014). The bands at 1718 and $1675 \mathrm{~cm}^{-1}$ correspond to $v(\mathrm{C}=\mathrm{O})$ (Divya et al., 2020; Vu et al., 2019) and those at 1578 and $1478 \mathrm{~cm}^{-1}$ to $v_{\mathrm{sym}}(\mathrm{C}-\mathrm{N}$ ) (Surinwong et al., 2014). The wavenumbers of the vibrations involving the $\mathrm{N}-$ $\mathrm{H}, \mathrm{C}=\mathrm{N}$ and $\mathrm{C}=\mathrm{O}$ groups are affected by the partial delocalization of electron charge density on one part of the ring, as shown in Fig. 2, and by the to coordination of $\mathrm{C}=\mathrm{O}$ oxygen to $\mathrm{Li}^{+}$. Finally the bands at 870,784 and $559 \mathrm{~cm}^{-1}$ are attributed to the characteristic vibrations of the 1,3,5-triazine ring (Bourzami et al., 2018; Bellardita et al., 2018).

\section{Absorption spectroscopy}

The UV-Vis NIR absorption spectrum was measured using a Perkin Elmer lambda 950 UV-Vis-NIR spectrophotometer (Fig. 6). The peaks observed at 290 and $228 \mathrm{~nm}$ are due to $\pi-$ $\pi^{*}$ and $\mathrm{n}-\pi^{*}$ transitions, respectively (Qiu \& Gao, 2005; Moreno-Guerra et al., 2019). The band gap, $E_{\mathrm{g}}$, can be estimated from the maximum absorption at $228 \mathrm{~nm}$ using the following equations. The optical absorption coefficient, $\alpha$, is related to the absorbance, $A$, by the relations: $\alpha=2.303 \mathrm{~A} / \mathrm{t}$ and $\alpha=A\left(h v-E_{\mathrm{g}}\right)^{1 / 2} / \mathrm{h} v$, where $t$ is the thickness of the crystal $(1 \mathrm{~mm})$ and $\mathrm{h} v$ is the photon energy. A plot of $(\alpha h v)^{2}$ versus $h v$ is shown as the inset in Fig. 7, from which the band gap $\left(E_{\mathrm{g}}\right)$ is estimated to be $5.22 \mathrm{eV}$.

\section{Thermogravimetric and differential thermal analysis} Simultaneous TG-DTA measurements and analysis of weight change and heat flow were performed using a Perkin Elmer STA 6000 instrument operating at a scanning rate of $10^{\circ} \mathrm{C}$

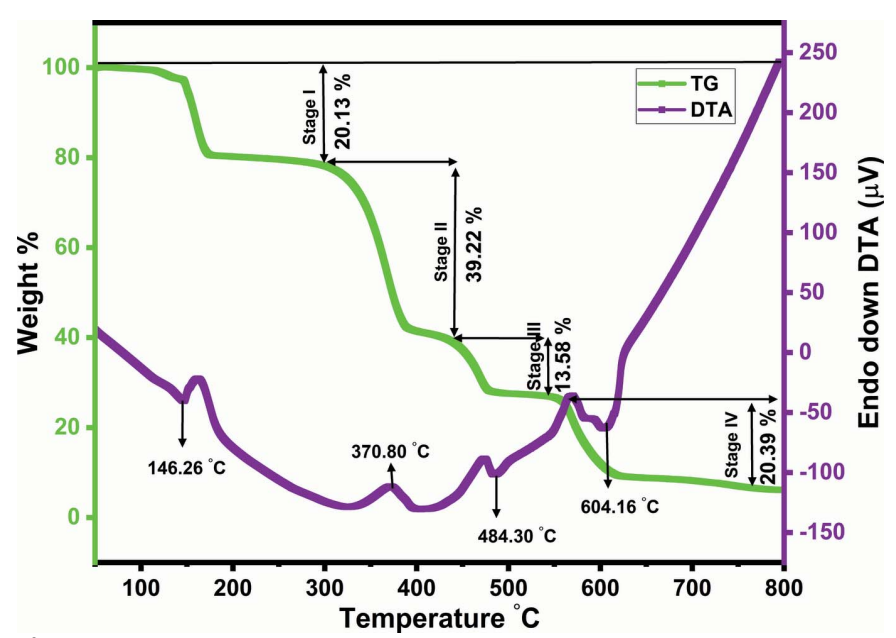

Figure 7

TG-DTA of the title compound measured under an $\mathrm{N}_{2}$ atmosphere using

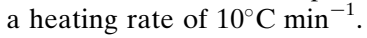


$\min ^{-1}$ with a resolution of $1 \mu \mathrm{g}$ under a dry $\mathrm{N}_{2}$ atmosphere. The thermogram (Fig. 7) shows four stages of decomposition. The first stage starts at $92^{\circ} \mathrm{C}$ and ends at $172^{\circ} \mathrm{C}$ with a derivative peak at $146.26^{\circ} \mathrm{C}$ and a measured weight loss of $20.13 \%$, which is in reasonable agreement with the loss of the seven coordinated water molecules (calculated weight loss 18.91\%). The second and third stages of decomposition, occurring from 298 to $550^{\circ} \mathrm{C}$, correspond to the decomposition of the cyanurate ligands with a measured total weight loss of $52.80 \%$, leading to the formation of $\mathrm{LiNO}_{3}$ (calculated weight loss $51.07 \%$ ) (Divya et al., 2020). In the fourth decomposition stage, occurring from 550 to $662^{\circ} \mathrm{C}, \mathrm{LiNO}_{3}$ decomposes with a measured weight loss of $20.39 \%$ to produce $\mathrm{Li}_{2} \mathrm{O}$ as the final solid residue (calculated weight loss $21.67 \%$ ).

\section{Synthesis and crystallization}

Lithium hydroxide (1.25 g, $0.052 \mathrm{~mol}$; LOBA) and cyanuric chloride (1.84 g, $0.01 \mathrm{~mol}$; Sigma-Aldrich) were dissolved in water $(100 \mathrm{ml})$. The resulting solution was stirred for $5 \mathrm{~h}$ at ambient temperature (300-301 K) and filtered twice using Whatman filter paper. The solvent was allowed to evaporate in a dust-free environment. After 22 days, good quality colourless crystals were harvested.

\section{Refinement}

Crystal data, data collection and structure refinement details are summarized in Table 2. Li2 was found to be disordered over two positions, $\mathrm{Li} 2 A$ and $\mathrm{Li} 2 B$, which were resolved using the PART command (Sheldrick, 2015b) with an occupancy ratio of 0.501 (6):0.499 (6). The $\mathrm{N}$-bound $\mathrm{H}$ atoms were placed geometrically and refined using a riding model with respect to their parent atoms using AFIX 43 with $\mathrm{N}-\mathrm{H}=0.86 \AA$ and $U_{\text {iso }}(\mathrm{H})=1.2 U_{\text {eq }}(\mathrm{N})$. The hydrogen atoms on the water molecules were located in difference-Fourier maps and each $U_{\text {iso }}(\mathrm{H})$ parameter was freely refined with the $\mathrm{O}-\mathrm{H}$ distance restrained to 0.85 (2) $\AA$ using DFIX. The $\mathrm{H}-\mathrm{O}-\mathrm{H}$ angle distances were restrained using DFIX to a target value of 1.39 (2) $\AA$ [or 1.41 (2) $\AA$ for $\mathrm{H} 9 A-\mathrm{O} 9-\mathrm{H} 9 B$ ] in order to keep the water molecules close to their standard geometries.

\section{Acknowledgements}

We acknowledge the support and encouragement of Dr S. Manivannan, Dean Phase II and Er. A. C. S. Arunkumar, President of Dr. M.G.R. Educational and Research Institute, Chennai, India.

\section{References}

Abu-Salem, Q., Harb, M. K., Maichle-Mössmer, C., Steimann, M. \& Voelter, W. (2017). Arab. J. Chem. 10, S3883-S3888.

Bellardita, M., García-López, E. I., Marcì, G., Krivtsov, I., García, J. R. \& Palmisano, L. (2018). Appl. Catal. Environ. 220, 222233.

Bourzami, R., AitYoucef, H. C., Hamdouni, N. \& Sebais, M. (2018). Chem. Phys. Lett. 711, 220-226.
Table 2

Experimental details.

\begin{tabular}{|c|c|}
\hline \multicolumn{2}{|l|}{ Crystal data } \\
\hline Chemical formula & {$\left[\mathrm{Li}_{4}\left(\mathrm{C}_{3} \mathrm{H}_{2} \mathrm{~N}_{3} \mathrm{O}_{3}\right)_{4}\left(\mathrm{H}_{2} \mathrm{O}\right)_{7}\right]$} \\
\hline$M_{\mathrm{r}}$ & 666.17 \\
\hline Crystal system, space group & Triclinic, $P \overline{1}$ \\
\hline Temperature (K) & 296 \\
\hline$a, b, c(\AA)$ & $8.8530(5), 9.0592(6), 9.6621(6)$ \\
\hline$\alpha, \beta, \gamma\left({ }^{\circ}\right)$ & $67.806(2), 62.887(2), 68.580(2)$ \\
\hline$V\left(\AA^{3}\right)$ & $620.89(7)$ \\
\hline$Z$ & 1 \\
\hline Radiation type & Мо $K \alpha$ \\
\hline$\mu\left(\mathrm{mm}^{-1}\right)$ & 0.16 \\
\hline Crystal size $(\mathrm{mm})$ & $0.15 \times 0.15 \times 0.10$ \\
\hline \multicolumn{2}{|l|}{ Data collection } \\
\hline Diffractometer & Bruker Kappa APEX3 CMOS \\
\hline Absorption correction & $\begin{array}{l}\text { Multi-scan (SADABS; Bruker, } \\
\text { 2016) }\end{array}$ \\
\hline$T_{\min }, T_{\max }$ & $0.707,0.746$ \\
\hline $\begin{array}{l}\text { No. of measured, independent and } \\
\text { observed }[I>2 \sigma(I)] \text { reflections }\end{array}$ & $17961,2181,1917$ \\
\hline$R_{\text {int }}$ & 0.027 \\
\hline$(\sin \theta / \lambda)_{\max }\left(\AA^{-1}\right)$ & 0.594 \\
\hline \multicolumn{2}{|l|}{ Refinement } \\
\hline$R\left[F^{2}>2 \sigma\left(F^{2}\right)\right], w R\left(F^{2}\right), S$ & $0.039,0.115,1.14$ \\
\hline No. of reflections & 2181 \\
\hline No. of parameters & 250 \\
\hline No. of restraints & 12 \\
\hline $\mathrm{H}$-atom treatment & $\begin{array}{l}\mathrm{H} \text { atoms treated by a mixture of } \\
\text { independent and constrained } \\
\text { refinement }\end{array}$ \\
\hline$\Delta \rho_{\max }, \Delta \rho_{\min }\left(\mathrm{e} \AA^{-3}\right)$ & $0.38,-0.32$ \\
\hline
\end{tabular}

Computer programs: APEX3, SAINT/XPREP (Bruker, 2016), SHELXT2014/5 (Sheldrick, 2015a), SHELXL2018/3 (Sheldrick, 2015b), ORTEP-3 for Windows (Farrugia, 2012) and Mercury (Macrae et al., 2020).

Bruker (2016). APEX3, SADABS, SAINT and XPREP. Bruker AXS Inc., Madison, Wisconsin, USA.

Chatenever, A. R. K., Warne, L. R., Matsuoka, J. E., Wang, S. J., Reinheimer, E. W., LeMagueres, P., Fei, H., Song, X. \& Oliver, S. R. J. (2019). Cryst. Growth Des. 19, 4854-4859.

Cho, S., Shi, K., Seffernick, J. L., Dodge, A. G., Wackett, L. P. \& Aihara, H. (2014). PLoS One, 9, https://doi.org/10.1371/journal.pone.0099349.

Coubrough, H. M., van der Lubbe, S. C. C., Hetherington, K., Minard, A., Pask, C., Howard, M. J., Fonseca Guerra, C. \& Wilson, A. J. (2019). Chem. Eur. J. 25, 785-795.

Divya, R., Nair, L. P., Bijini, B. R., Nair, C. M. K., Gopakumar, N. \& Babu, K. R. (2017). Physica B, 526, 37-44.

Divya, R., Vineeth, V. T., Bijini, B. R., Nair, C. M. K. \& RajendraBabu, K. (2020). J. Mol. Struct. 1200, 127031.

Farrugia, L. J. (2012). J. Appl. Cryst. 45, 849-854.

Ge, Z. Y., Zhu, Z. B., Deng, Z. P., Huo, L. H. \& Gao, S. (2018). CrystEngComm, 20, 2968-2979.

Groom, C. R., Bruno, I. J., Lightfoot, M. P. \& Ward, S. C. (2016). Acta Cryst. B72, 171-179.

Ivanova, I. S., Ilyukhin, A. B., Tsebrikova, G. S., Polyakova, I. N., Pyatova, E. N., Solov'ev, V. P., Baulin, V. E. \& Yu. Tsivadze, A. (2019). Inorg. Chim. Acta, 497, 119095.

Jeseentharani, V., Selvakumar, J., Dayalan, A., Varghese, B. \& Nagaraja, K. S. (2010). J. Mol. Struct. 966, 122-128.

Macrae, C. F., Sovago, I., Cottrell, S. J., Galek, P. T. A., McCabe, P., Pidcock, E., Platings, M., Shields, G. P., Stevens, J. S., Towler, M. \& Wood, P. A. (2020). J. Appl. Cryst. 53, 226-235.

Moreno-Guerra, J. A., Oliva, J., Vallejo, M. A., Bernal-Alvarado, J., Sosa, M., Villasenor-Mora, C., Ceron, P. \& Gomez-Solis, C. (2019). J. Lumin. 215, 116673. 
Pan, P., Shan, G., Bao, Y. \& Weng, Z. (2013). J. Appl. Polym. Sci. 129, 1374-1382.

Prabhaharan, M., Prabakaran, A. R., Srinivasan, S. \& Gunasekaran, S. (2015). Spectrochim. Acta, A138, 711-722.

Qiu, Y. \& Gao, L. (2005). Mater. Res. Bull. 40, 794-799.

Qu, X. L., Zheng, X. L. \& Li, X. (2016). RSC Adv. 6, 69007-69015. Sheldrick, G. M. (2015a). Acta Cryst. C71, 3-8.

Sheldrick, G. M. (2015b). Acta Cryst. A71, 3-8.

Shemchuk, O., Braga, D., Maini, L. \& Grepioni, F. (2017). CrystEngComm, 19, 1366-1369.
Suguna, S., Anbuselvi, D., Jayaraman, D., Nagaraja, K. S. \& Jeyaraj, B. (2014). Spectrochim. Acta, A132, 330-338.

Surinwong, S., Prior, T. J. \& Rujiwatra, A. (2014). J. Sci. 41, 414-423.

Vu, N. N., Nguyen, C. C., Kaliaguine, S. \& Do, T. O. (2019). ChemSusChem, 12, 291-302.

Wan, W., Zhu, Z.-B., Huo, L.-H., Deng, Z.-P., Zhao, H. \& Gao, S. (2012). CrystEngComm, 14, 5274-5284.

Weng, M. \& Qiu, Z. (2014). Thermochim. Acta, 577, 41-45.

Yue, Q., Yang, J., Yuan, H. M. \& Chen, J. S. (2006). Chin. J. Chem. 24, 1045-1049. 


\section{supporting information}

Acta Cryst. (2021). E77, 1019-1024 [https://doi.org/10.1107/S2056989021009324]

\section{Polymeric coordination complex of lithium(I) with aqua and cyanurate ligands}

\section{Anjapuli Ponnuvel, Arumugam Pillai Kala, Karachalacherevu Seetharamiah Nagaraja and Chandran Karnan}

Computing details

Data collection: APEX3 (Bruker, 2016); cell refinement: APEX3/SAINT (Bruker, 2016); data reduction: SAINT/XPREP (Bruker, 2016); program(s) used to solve structure: SHELXT2014/5 (Sheldrick, 2015a); program(s) used to refine structure: SHELXL2018/3 (Sheldrick, 2015b); molecular graphics: ORTEP-3 for Windows (Farrugia, 2012) and Mercury (Macrae et al., 2020); software used to prepare material for publication: SHELXL2018/3 (Sheldrick, 2015b).

Poly[ $\mu_{3}$-aqua-hexa- $\mu_{2}$-aqua-tetra- $\mu$-cyanurato-tetralithium]

Crystal data

$\left[\mathrm{Li}_{4}\left(\mathrm{C}_{3} \mathrm{H}_{2} \mathrm{~N}_{3} \mathrm{O}_{3}\right)_{4}\left(\mathrm{H}_{2} \mathrm{O}\right)_{7}\right]$

$M_{r}=666.17$

Triclinic, $P \overline{1}$

$a=8.8530(5) \AA$

$b=9.0592(6) \AA$

$c=9.6621(6) \AA$

$\alpha=67.806(2)^{\circ}$

$\beta=62.887(2)^{\circ}$

$\gamma=68.580(2)^{\circ}$

$V=620.89(7) \AA^{3}$

Data collection

Bruker Kappa APEX3 CMOS diffractometer

Radiation source: fine-focus sealed tube

Graphite monochromator

$\omega$ and $\varphi$ scan

Absorption correction: multi-scan

(SADABS; Bruker, 2016)

$T_{\min }=0.707, T_{\max }=0.746$

Refinement

Refinement on $F^{2}$

Least-squares matrix: full

$R\left[F^{2}>2 \sigma\left(F^{2}\right)\right]=0.039$

$w R\left(F^{2}\right)=0.115$

$S=1.14$

2181 reflections

250 parameters

12 restraints
$Z=1$

$F(000)=342$

$D_{\mathrm{x}}=1.782 \mathrm{Mg} \mathrm{m}^{-3}$

Mo $K \alpha$ radiation, $\lambda=0.71073 \AA$

Cell parameters from 9866 reflections

$\theta=3.2-30.5^{\circ}$

$\mu=0.16 \mathrm{~mm}^{-1}$

$T=296 \mathrm{~K}$

Block, colourless

$0.15 \times 0.15 \times 0.10 \mathrm{~mm}$

17961 measured reflections

2181 independent reflections

1917 reflections with $I>2 \sigma(I)$

$R_{\text {int }}=0.027$

$\theta_{\max }=25.0^{\circ}, \theta_{\min }=2.9^{\circ}$

$h=-10 \rightarrow 10$

$k=-10 \rightarrow 10$

$l=-11 \rightarrow 11$

Hydrogen site location: mixed

$\mathrm{H}$ atoms treated by a mixture of independent and constrained refinement

$w=1 /\left[\sigma^{2}\left(F_{\mathrm{o}}^{2}\right)+(0.0656 P)^{2}+0.1885 P\right]$

where $P=\left(F_{\mathrm{o}}^{2}+2 F_{\mathrm{c}}^{2}\right) / 3$

$(\Delta / \sigma)_{\max }<0.001$

$\Delta \rho_{\max }=0.38 \mathrm{e} \AA^{-3}$

$\Delta \rho_{\min }=-0.31$ e $\AA^{-3}$ 


\section{Special details}

Geometry. All esds (except the esd in the dihedral angle between two 1.s. planes) are estimated using the full covariance matrix. The cell esds are taken into account individually in the estimation of esds in distances, angles and torsion angles; correlations between esds in cell parameters are only used when they are defined by crystal symmetry. An approximate (isotropic) treatment of cell esds is used for estimating esds involving l.s. planes.

Fractional atomic coordinates and isotropic or equivalent isotropic displacement parameters $\left(\AA^{2}\right)$

\begin{tabular}{|c|c|c|c|c|c|}
\hline & $x$ & $y$ & $z$ & $U_{\text {iso }} * / U_{\text {eq }}$ & Occ. $(<1)$ \\
\hline Li1 & $0.8785(3)$ & $0.4997(3)$ & $0.6728(3)$ & $0.0273(6)$ & \\
\hline Li2A & $0.6581(8)$ & $0.5613(9)$ & $1.0527(8)$ & $0.0372(10)$ & $0.501(6)$ \\
\hline Li2B & $0.6884(8)$ & $0.4388(9)$ & $1.0835(8)$ & $0.0372(10)$ & $0.499(6)$ \\
\hline $\mathrm{C} 1$ & $0.84110(19)$ & $0.13728(18)$ & $0.83772(17)$ & $0.0162(3)$ & \\
\hline $\mathrm{C} 2$ & 0.75963 (19) & $-0.12382(18)$ & $0.95319(17)$ & $0.0167(3)$ & \\
\hline $\mathrm{C} 3$ & $1.05252(19)$ & $-0.12405(18)$ & $0.85818(17)$ & $0.0172(3)$ & \\
\hline $\mathrm{C} 4$ & $0.65967(18)$ & $0.86155(18)$ & $0.65700(17)$ & $0.0159(3)$ & \\
\hline $\mathrm{C} 5$ & $0.44821(19)$ & $1.12286(18)$ & $0.64435(17)$ & 0.0165 (3) & \\
\hline C6 & $0.74036(19)$ & $1.12290(18)$ & $0.54318(17)$ & $0.0167(3)$ & \\
\hline N1 & $0.71916(16)$ & $0.04611(15)$ & $0.91183(15)$ & $0.0186(3)$ & \\
\hline H1 & 0.611046 & 0.096942 & 0.934161 & $0.022 *$ & \\
\hline $\mathrm{N} 2$ & $0.92688(16)$ & $-0.20772(15)$ & $0.92701(15)$ & $0.0196(3)$ & \\
\hline N3 & $1.00835(16)$ & $0.04588(16)$ & $0.81138(15)$ & $0.0190(3)$ & \\
\hline $\mathrm{H} 3$ & 1.091204 & 0.096662 & 0.762906 & $0.023 *$ & \\
\hline N4 & $0.49252(16)$ & $0.95287(15)$ & $0.68709(15)$ & $0.0186(3)$ & \\
\hline $\mathrm{H} 4$ & 0.409623 & 0.902156 & 0.735402 & $0.022 *$ & \\
\hline N5 & $0.57311(16)$ & $1.20723(15)$ & $0.57313(15)$ & $0.0187(3)$ & \\
\hline N6 & $0.78129(15)$ & $0.95284(15)$ & $0.58268(15)$ & $0.0186(3)$ & \\
\hline H6 & 0.889544 & 0.902188 & 0.558918 & $0.022 *$ & \\
\hline $\mathrm{O} 1$ & $0.80308(14)$ & $0.28696(13)$ & $0.79896(13)$ & $0.0236(3)$ & \\
\hline $\mathrm{O} 2$ & $1.20853(13)$ & $-0.19384(13)$ & $0.83558(14)$ & $0.0255(3)$ & \\
\hline $\mathrm{O} 3$ & $0.63820(13)$ & $-0.19370(13)$ & $1.01218(14)$ & $0.0250(3)$ & \\
\hline $\mathrm{O} 4$ & $0.69679(14)$ & $0.71143(13)$ & $0.69329(13)$ & $0.0232(3)$ & \\
\hline O5 & $0.29078(13)$ & 1.19154 (13) & $0.67448(14)$ & $0.0247(3)$ & \\
\hline O6 & $0.86314(13)$ & 1.19169 (13) & $0.48001(14)$ & $0.0254(3)$ & \\
\hline O7 & $0.89868(15)$ & 0.49969 (14) & $0.89151(14)$ & $0.0262(3)$ & \\
\hline O8 & $1.13401(15)$ & 0.50005 (14) & $0.53775(14)$ & $0.0247(3)$ & \\
\hline O9 & 0.500000 & 0.500000 & 1.000000 & $0.0469(6)$ & \\
\hline $\mathrm{O} 10$ & $0.5956(2)$ & $0.50030(18)$ & $1.28285(17)$ & $0.0489(4)$ & \\
\hline H7A & $0.939(3)$ & $0.582(2)$ & $0.877(3)$ & $0.064(8)^{*}$ & \\
\hline H7B & $0.981(3)$ & $0.415(2)$ & $0.915(3)$ & $0.059(7)^{*}$ & \\
\hline $\mathrm{H} 8 \mathrm{~A}$ & $1.158(3)$ & $0.5834(19)$ & $0.538(3)$ & $0.039(6)^{*}$ & \\
\hline H8B & $1.201(3)$ & $0.415(2)$ & $0.577(3)$ & $0.047(6)^{*}$ & \\
\hline H9A & $0.433(6)$ & $0.584(4)$ & $1.047(5)$ & $0.057(15)^{*}$ & 0.5 \\
\hline H9B & $0.472(6)$ & $0.418(4)$ & $1.089(4)$ & $0.043(13)^{*}$ & 0.5 \\
\hline H10A & $0.543(4)$ & $0.585(2)$ & $1.323(3)$ & $0.069(8)^{*}$ & \\
\hline H10B & $0.581(3)$ & $0.418(2)$ & $1.365(2)$ & $0.062(8)^{*}$ & \\
\hline
\end{tabular}


Atomic displacement parameters $\left(\AA^{2}\right)$

\begin{tabular}{lllllll}
\hline & $U^{11}$ & $U^{22}$ & $U^{33}$ & $U^{12}$ & $U^{13}$ & $U^{23}$ \\
\hline Li1 & $0.0251(13)$ & $0.0217(14)$ & $0.0277(13)$ & $-0.0063(11)$ & $-0.0042(11)$ & $-0.0048(11)$ \\
Li2A & $0.033(2)$ & $0.039(2)$ & $0.035(2)$ & $-0.010(2)$ & $-0.0070(18)$ & $-0.010(2)$ \\
Li2B & $0.033(2)$ & $0.039(2)$ & $0.035(2)$ & $-0.010(2)$ & $-0.0070(18)$ & $-0.010(2)$ \\
C1 & $0.0177(7)$ & $0.0159(8)$ & $0.0150(7)$ & $-0.0045(6)$ & $-0.0050(6)$ & $-0.0045(6)$ \\
C2 & $0.0165(7)$ & $0.0161(8)$ & $0.0172(7)$ & $-0.0049(6)$ & $-0.0052(6)$ & $-0.0043(6)$ \\
C3 & $0.0157(7)$ & $0.0173(8)$ & $0.0169(7)$ & $-0.0037(6)$ & $-0.0048(6)$ & $-0.0042(6)$ \\
C4 & $0.0168(7)$ & $0.0145(8)$ & $0.0154(7)$ & $-0.0020(6)$ & $-0.0064(6)$ & $-0.0039(6)$ \\
C5 & $0.0162(7)$ & $0.0156(8)$ & $0.0165(7)$ & $-0.0026(6)$ & $-0.0065(6)$ & $-0.0034(6)$ \\
C6 & $0.0160(7)$ & $0.0164(8)$ & $0.0174(7)$ & $-0.0041(6)$ & $-0.0051(6)$ & $-0.0052(6)$ \\
N1 & $0.0122(6)$ & $0.0141(7)$ & $0.0268(7)$ & $-0.0016(5)$ & $-0.0059(5)$ & $-0.0056(5)$ \\
N2 & $0.0157(7)$ & $0.0144(7)$ & $0.0263(7)$ & $-0.0036(5)$ & $-0.0071(5)$ & $-0.0033(5)$ \\
N3 & $0.0143(6)$ & $0.0152(7)$ & $0.0246(7)$ & $-0.0068(5)$ & $-0.0047(5)$ & $-0.0020(5)$ \\
N4 & $0.0134(6)$ & $0.0140(7)$ & $0.0248(7)$ & $-0.0050(5)$ & $-0.0054(5)$ & $-0.0017(5)$ \\
N5 & $0.0163(7)$ & $0.0135(7)$ & $0.0249(7)$ & $-0.0035(5)$ & $-0.0078(5)$ & $-0.0034(5)$ \\
N6 & $0.0112(6)$ & $0.0143(7)$ & $0.0266(7)$ & $-0.0010(5)$ & $-0.0052(5)$ & $-0.0054(5)$ \\
O1 & $0.0246(6)$ & $0.0127(6)$ & $0.0303(6)$ & $-0.0043(5)$ & $-0.0097(5)$ & $-0.0029(5)$ \\
O2 & $0.0128(5)$ & $0.0211(6)$ & $0.0370(7)$ & $-0.0023(4)$ & $-0.0075(5)$ & $-0.0054(5)$ \\
O3 & $0.0156(6)$ & $0.0189(6)$ & $0.0372(7)$ & $-0.0076(5)$ & $-0.0064(5)$ & $-0.0047(5)$ \\
O4 & $0.0219(6)$ & $0.0127(6)$ & $0.0307(6)$ & $-0.0019(5)$ & $-0.0089(5)$ & $-0.0041(5)$ \\
O5 & $0.0129(5)$ & $0.0177(6)$ & $0.0370(7)$ & $-0.0014(4)$ & $-0.0082(5)$ & $-0.0038(5)$ \\
O6 & $0.0156(6)$ & $0.0189(6)$ & $0.0393(7)$ & $-0.0066(5)$ & $-0.0070(5)$ & $-0.0064(5)$ \\
O7 & $0.0294(6)$ & $0.0196(6)$ & $0.0330(7)$ & $-0.0040(5)$ & $-0.0164(5)$ & $-0.0056(5)$ \\
O8 & $0.0237(6)$ & $0.0185(6)$ & $0.0313(6)$ & $-0.0047(5)$ & $-0.0108(5)$ & $-0.0049(5)$ \\
O9 & $0.0230(10)$ & $0.0917(18)$ & $0.0275(10)$ & $-0.0221(11)$ & $0.0023(8)$ & $-0.0229(12)$ \\
O10 & $0.0759(11)$ & $0.0278(8)$ & $0.0380(8)$ & $-0.0076(7)$ & $-0.0217(8)$ & $-0.0066(6)$ \\
& & & & & & \\
\hline & & & & & & \\
\hline
\end{tabular}

Geometric parameters $\left(A,{ }^{\circ}\right)$

\begin{tabular}{|c|c|c|c|}
\hline $\mathrm{Li} 1-\mathrm{O} 4$ & $2.012(3)$ & $\mathrm{C} 3-\mathrm{N} 3$ & $1.387(2)$ \\
\hline $\mathrm{Li} 1-\mathrm{O} 1$ & $2.017(3)$ & $\mathrm{C} 4-\mathrm{O} 4$ & $1.2242(19)$ \\
\hline $\mathrm{Li} 1-\mathrm{O} 8$ & $2.032(3)$ & $\mathrm{C} 4-\mathrm{N} 4$ & $1.362(2)$ \\
\hline $\mathrm{Li} 1-\mathrm{O}^{\mathrm{i}}$ & $2.086(3)$ & $\mathrm{C} 4-\mathrm{N} 6$ & $1.362(2)$ \\
\hline $\mathrm{Li} 1-\mathrm{O} 7$ & $2.201(3)$ & $\mathrm{C} 5-\mathrm{O} 5$ & $1.2442(18)$ \\
\hline Li1-Li1 ${ }^{\mathrm{i}}$ & $3.037(5)$ & $\mathrm{C} 5-\mathrm{N} 5$ & $1.344(2)$ \\
\hline Li1-Li2A & $3.438(7)$ & $\mathrm{C} 5-\mathrm{N} 4$ & $1.386(2)$ \\
\hline Li1-Li2B & $3.439(7)$ & $\mathrm{C} 6-\mathrm{O} 6$ & $1.2430(18)$ \\
\hline $\mathrm{Li} 2 \mathrm{~A}-\mathrm{O} 10$ & $1.931(7)$ & $\mathrm{C} 6-\mathrm{N} 5$ & $1.345(2)$ \\
\hline $\mathrm{Li} 2 \mathrm{~A}-\mathrm{O} 9$ & $1.989(6)$ & C6-N6 & $1.387(2)$ \\
\hline $\mathrm{Li} 2 \mathrm{~A}-\mathrm{O} 7$ & $2.010(6)$ & $\mathrm{N} 1-\mathrm{H} 1$ & 0.8600 \\
\hline $\mathrm{Li} 2 \mathrm{~A}-\mathrm{O} 3^{\mathrm{ii}}$ & $2.057(7)$ & $\mathrm{N} 3-\mathrm{H} 3$ & 0.8600 \\
\hline $\mathrm{Li} 2 \mathrm{~B}-\mathrm{O} 10$ & $1.931(7)$ & $\mathrm{N} 4-\mathrm{H} 4$ & 0.8600 \\
\hline $\mathrm{Li} 2 \mathrm{~B}-\mathrm{O} 9$ & $1.988(7)$ & N6-H6 & 0.8600 \\
\hline $\mathrm{Li} 2 \mathrm{~B}-\mathrm{O} 7$ & $2.010(6)$ & $\mathrm{O} 7-\mathrm{H} 7 \mathrm{~A}$ & $0.880(16)$ \\
\hline $\mathrm{Li} 2 \mathrm{~B}-\mathrm{O} 2^{\mathrm{iii}}$ & $2.056(7)$ & $\mathrm{O} 7-\mathrm{H} 7 \mathrm{~B}$ & $0.883(16)$ \\
\hline $\mathrm{C} 1-\mathrm{O} 1$ & $1.2207(19)$ & $\mathrm{O} 8-\mathrm{H} 8 \mathrm{~A}$ & $0.857(15)$ \\
\hline
\end{tabular}




\begin{tabular}{|c|c|c|c|}
\hline $\mathrm{C} 1-\mathrm{N} 1$ & $1.364(2)$ & $\mathrm{O} 8-\mathrm{H} 8 \mathrm{~B}$ & $0.862(15)$ \\
\hline $\mathrm{C} 1-\mathrm{N} 3$ & $1.365(2)$ & O9-H9A & $0.905(19)$ \\
\hline $\mathrm{C} 2-\mathrm{O} 3$ & $1.2439(18)$ & O9- $\mathrm{H} 9 \mathrm{~B}$ & 0.898 (19) \\
\hline $\mathrm{C} 2-\mathrm{N} 2$ & $1.348(2)$ & O9-H9A ${ }^{\text {iv }}$ & $0.905(19)$ \\
\hline $\mathrm{C} 2-\mathrm{N} 1$ & $1.386(2)$ & $\mathrm{O} 9-\mathrm{H} 9 \mathrm{~B}^{\mathrm{iv}}$ & $0.898(19)$ \\
\hline $\mathrm{C} 3-\mathrm{O} 2$ & $1.2436(19)$ & $\mathrm{O} 10-\mathrm{H} 10 \mathrm{~A}$ & $0.872(16)$ \\
\hline $\mathrm{C} 3-\mathrm{N} 2$ & $1.347(2)$ & $\mathrm{O} 10-\mathrm{H} 10 \mathrm{~B}$ & $0.859(16)$ \\
\hline $\mathrm{O} 4-\mathrm{Li} 1-\mathrm{O} 1$ & $118.40(13)$ & $\mathrm{O} 4-\mathrm{C} 4-\mathrm{N} 6$ & $123.28(13)$ \\
\hline $\mathrm{O} 4-\mathrm{Li} 1-\mathrm{O} 8$ & $120.78(14)$ & $\mathrm{N} 4-\mathrm{C} 4-\mathrm{N} 6$ & $113.72(13)$ \\
\hline $\mathrm{O} 1-\mathrm{Li} 1-\mathrm{O} 8$ & $120.74(14)$ & $\mathrm{O} 5-\mathrm{C} 5-\mathrm{N} 5$ & $122.46(14)$ \\
\hline $\mathrm{O} 4-\mathrm{Li} 1-\mathrm{O}^{\mathrm{i}}$ & $93.98(13)$ & $\mathrm{O} 5-\mathrm{C} 5-\mathrm{N} 4$ & $117.42(13)$ \\
\hline $\mathrm{O} 1-\mathrm{Li} 1-\mathrm{O}^{\mathrm{i}}$ & $94.00(13)$ & $\mathrm{N} 5-\mathrm{C} 5-\mathrm{N} 4$ & $120.13(13)$ \\
\hline $\mathrm{O} 8-\mathrm{Li} 1-\mathrm{O}^{\mathrm{i}}$ & $85.00(11)$ & $\mathrm{O} 6-\mathrm{C} 6-\mathrm{N} 5$ & $122.42(14)$ \\
\hline $\mathrm{O} 4-\mathrm{Li} 1-\mathrm{O} 7$ & $86.70(11)$ & $\mathrm{O} 6-\mathrm{C} 6-\mathrm{N} 6$ & $117.45(13)$ \\
\hline $\mathrm{O} 1-\mathrm{Li} 1-\mathrm{O} 7$ & $86.78(11)$ & $\mathrm{N} 5-\mathrm{C} 6-\mathrm{N} 6$ & $120.13(13)$ \\
\hline $\mathrm{O} 8-\mathrm{Li} 1-\mathrm{O} 7$ & $93.57(12)$ & $\mathrm{C} 1-\mathrm{N} 1-\mathrm{C} 2$ & $123.71(13)$ \\
\hline 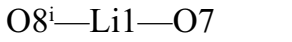 & $178.56(15)$ & $\mathrm{C} 1-\mathrm{N} 1-\mathrm{H} 1$ & 118.1 \\
\hline $\mathrm{O} 10-\mathrm{Li} 2 \mathrm{~A}-\mathrm{O} 9$ & $109.9(3)$ & $\mathrm{C} 2-\mathrm{N} 1-\mathrm{H} 1$ & 118.1 \\
\hline $\mathrm{O} 10-\mathrm{Li} 2 \mathrm{~A}-\mathrm{O} 7$ & $125.3(3)$ & $\mathrm{C} 3-\mathrm{N} 2-\mathrm{C} 2$ & $119.06(13)$ \\
\hline $\mathrm{O} 9-\mathrm{Li} 2 \mathrm{~A}-\mathrm{O} 7$ & $105.8(3)$ & $\mathrm{C} 1-\mathrm{N} 3-\mathrm{C} 3$ & $123.85(12)$ \\
\hline $\mathrm{O} 10-\mathrm{Li} 2 \mathrm{~A}-\mathrm{O}^{\mathrm{ii}}$ & $97.9(3)$ & $\mathrm{C} 1-\mathrm{N} 3-\mathrm{H} 3$ & 118.1 \\
\hline $\mathrm{O} 9-\mathrm{Li} 2 \mathrm{~A}-\mathrm{O} 3^{\mathrm{ii}}$ & $118.3(3)$ & $\mathrm{C} 3-\mathrm{N} 3-\mathrm{H} 3$ & 118.1 \\
\hline $\mathrm{O} 7-\mathrm{Li} 2 \mathrm{~A}-\mathrm{O} 3^{\mathrm{ii}}$ & $100.0(3)$ & $\mathrm{C} 4-\mathrm{N} 4-\mathrm{C} 5$ & $123.81(12)$ \\
\hline $\mathrm{O} 10-\mathrm{Li} 2 \mathrm{~B}-\mathrm{O} 9$ & $109.9(3)$ & $\mathrm{C} 4-\mathrm{N} 4-\mathrm{H} 4$ & 118.1 \\
\hline $\mathrm{O} 10-\mathrm{Li} 2 \mathrm{~B}-\mathrm{O} 7$ & $125.3(3)$ & $\mathrm{C} 5-\mathrm{N} 4-\mathrm{H} 4$ & 118.1 \\
\hline $\mathrm{O} 9-\mathrm{Li} 2 \mathrm{~B}-\mathrm{O} 7$ & $105.9(3)$ & $\mathrm{C} 5-\mathrm{N} 5-\mathrm{C} 6$ & $118.47(13)$ \\
\hline $\mathrm{O} 10-\mathrm{Li} 2 \mathrm{~B}-\mathrm{O} 2^{\mathrm{iii}}$ & $98.3(3)$ & $\mathrm{C} 4-\mathrm{N} 6-\mathrm{C} 6$ & $123.70(12)$ \\
\hline $\mathrm{O} 9-\mathrm{Li} 2 \mathrm{~B}-\mathrm{O} 2^{\mathrm{iii}}$ & $118.3(3)$ & $\mathrm{C} 4-\mathrm{N} 6-\mathrm{H} 6$ & 118.2 \\
\hline $\mathrm{O} 7-\mathrm{Li} 2 \mathrm{~B}-\mathrm{O} 2^{\mathrm{iii}}$ & $99.6(3)$ & $\mathrm{C} 6-\mathrm{N} 6-\mathrm{H} 6$ & 118.2 \\
\hline $\mathrm{O} 1-\mathrm{C} 1-\mathrm{N} 1$ & $122.71(13)$ & $\mathrm{C} 1-\mathrm{O} 1-\mathrm{Li} 1$ & $149.18(13)$ \\
\hline $\mathrm{O} 1-\mathrm{C} 1-\mathrm{N} 3$ & $123.42(13)$ & $\mathrm{C} 3-\mathrm{O} 2-\mathrm{Li} 2 \mathrm{~B}^{\mathrm{iii}}$ & $127.6(2)$ \\
\hline $\mathrm{N} 1-\mathrm{C} 1-\mathrm{N} 3$ & $113.86(13)$ & $\mathrm{C} 2-\mathrm{O} 3-\mathrm{Li}_{2} \mathrm{~A}^{\mathrm{v}}$ & $127.3(2)$ \\
\hline $\mathrm{O} 3-\mathrm{C} 2-\mathrm{N} 2$ & $122.20(14)$ & $\mathrm{C} 4-\mathrm{O} 4-\mathrm{Li} 1$ & $149.09(13)$ \\
\hline $\mathrm{O} 3-\mathrm{C} 2-\mathrm{N} 1$ & $117.99(13)$ & Li2A-O7-Li1 & $109.4(2)$ \\
\hline $\mathrm{N} 2-\mathrm{C} 2-\mathrm{N} 1$ & $119.80(13)$ & Li2B-O7-Li1 & $109.4(2)$ \\
\hline $\mathrm{O} 2-\mathrm{C} 3-\mathrm{N} 2$ & $122.28(14)$ & $\mathrm{Li} 1-\mathrm{O} 8-\mathrm{Li}^{\mathrm{i}}$ & $95.00(11)$ \\
\hline $\mathrm{O} 2-\mathrm{C} 3-\mathrm{N} 3$ & $118.11(13)$ & $\mathrm{H} 8 \mathrm{~A}-\mathrm{O} 8-\mathrm{H} 8 \mathrm{~B}$ & $106.4(17)$ \\
\hline $\mathrm{N} 2-\mathrm{C} 3-\mathrm{N} 3$ & $119.61(13)$ & $\mathrm{Li} 2 \mathrm{~A}^{\mathrm{iv}}-\mathrm{O} 9-\mathrm{Li} 2 \mathrm{~A}$ & 180.0 \\
\hline $\mathrm{O} 4-\mathrm{C} 4-\mathrm{N} 4$ & $123.00(13)$ & $\mathrm{H} 10 \mathrm{~A}-\mathrm{O} 10-\mathrm{H} 10 \mathrm{~B}$ & $104.5(19)$ \\
\hline $\mathrm{O} 1-\mathrm{C} 1-\mathrm{N} 1-\mathrm{C} 2$ & $178.28(13)$ & $\mathrm{O} 5-\mathrm{C} 5-\mathrm{N} 5-\mathrm{C} 6$ & $-179.15(14)$ \\
\hline $\mathrm{N} 3-\mathrm{C} 1-\mathrm{N} 1-\mathrm{C} 2$ & $-1.8(2)$ & $\mathrm{N} 4-\mathrm{C} 5-\mathrm{N} 5-\mathrm{C} 6$ & $0.8(2)$ \\
\hline $\mathrm{O} 3-\mathrm{C} 2-\mathrm{N} 1-\mathrm{C} 1$ & $-176.02(13)$ & $\mathrm{O} 6-\mathrm{C} 6-\mathrm{N} 5-\mathrm{C} 5$ & $-178.87(13)$ \\
\hline $\mathrm{N} 2-\mathrm{C} 2-\mathrm{N} 1-\mathrm{C} 1$ & $3.1(2)$ & $\mathrm{N} 6-\mathrm{C} 6-\mathrm{N} 5-\mathrm{C} 5$ & $1.2(2)$ \\
\hline $\mathrm{O} 2-\mathrm{C} 3-\mathrm{N} 2-\mathrm{C} 2$ & $177.57(14)$ & $\mathrm{O} 4-\mathrm{C} 4-\mathrm{N} 6-\mathrm{C} 6$ & $-179.04(13)$ \\
\hline $\mathrm{N} 3-\mathrm{C} 3-\mathrm{N} 2-\mathrm{C} 2$ & $-1.9(2)$ & $\mathrm{N} 4-\mathrm{C} 4-\mathrm{N} 6-\mathrm{C} 6$ & $1.1(2)$ \\
\hline $\mathrm{O} 3-\mathrm{C} 2-\mathrm{N} 2-\mathrm{C} 3$ & $177.99(13)$ & $\mathrm{O} 6-\mathrm{C} 6-\mathrm{N} 6-\mathrm{C} 4$ & $177.82(13)$ \\
\hline
\end{tabular}




$\begin{array}{llll}\mathrm{N} 1-\mathrm{C} 2-\mathrm{N} 2-\mathrm{C} 3 & -1.1(2) & \mathrm{N} 5-\mathrm{C} 6-\mathrm{N} 6-\mathrm{C} 4 & -2.3(2) \\ \mathrm{O} 1-\mathrm{C} 1-\mathrm{N} 3-\mathrm{C} 3 & 178.49(13) & \mathrm{N} 1-\mathrm{C} 1-\mathrm{O} 1-\mathrm{Li} 1 & -166.0(2) \\ \mathrm{N} 1-\mathrm{C} 1-\mathrm{N} 3-\mathrm{C} 3 & -1.5(2) & \mathrm{N} 3-\mathrm{C} 1-\mathrm{O} 1-\mathrm{Li} 1 & 14.1(3) \\ \mathrm{O} 2-\mathrm{C} 3-\mathrm{N} 3-\mathrm{C} 1 & -176.14(13) & \mathrm{N} 2-\mathrm{C} 3-\mathrm{O} 2-\mathrm{Li} 2 \mathrm{~B}^{\mathrm{iii}} & -8.1(3) \\ \mathrm{N} 2-\mathrm{C} 3-\mathrm{N} 3-\mathrm{C} 1 & 3.4(2) & \mathrm{N} 3-\mathrm{C} 3-\mathrm{O} 2-\mathrm{Li} 2 \mathrm{~B}^{\mathrm{iii}} & 171.4(2) \\ \mathrm{O} 4-\mathrm{C} 4-\mathrm{N} 4-\mathrm{C} 5 & -178.82(13) & \mathrm{N} 2-\mathrm{C} 2-\mathrm{O} 3-\mathrm{Li}_{2} \mathrm{~A}^{\mathrm{v}} & -9.5(3) \\ \mathrm{N} 6-\mathrm{C} 4-\mathrm{N} 4-\mathrm{C} 5 & 1.1(2) & \mathrm{N} 1-\mathrm{C} 2-\mathrm{O} 3-\mathrm{Li} 2 \mathrm{~A}^{\mathrm{v}} & 169.6(2) \\ \mathrm{O} 5-\mathrm{C} 5-\mathrm{N} 4-\mathrm{C} 4 & 177.88(13) & \mathrm{N} 4-\mathrm{C} 4-\mathrm{O} 4-\mathrm{Li} 1 & 166.5(2) \\ \mathrm{N} 5-\mathrm{C} 5-\mathrm{N} 4-\mathrm{C} 4 & -2.1(2) & \mathrm{N} 6-\mathrm{C} 4-\mathrm{O} 4-\mathrm{Li} 1 & -13.4(3)\end{array}$

Symmetry codes: (i) $-x+2,-y+1,-z+1$; (ii) $x, y+1, z$; (iii) $-x+2,-y,-z+2$; (iv) $-x+1,-y+1,-z+2$; (v) $x, y-1, z$.

Hydrogen-bond geometry $\left(A,{ }^{\circ}\right)$

\begin{tabular}{lllll}
\hline$D-\mathrm{H} \cdots A$ & $D-\mathrm{H}$ & $\mathrm{H} \cdots A$ & $D \cdots A$ & $D-\mathrm{H}^{\cdots} A$ \\
\hline $\mathrm{N} 1-\mathrm{H} 1 \cdots 3^{\text {vi }}$ & 0.86 & 1.95 & $2.8054(17)$ & 175 \\
$\mathrm{~N} 3-\mathrm{H} 3 \cdots 5^{\text {vii }}$ & 0.86 & 1.94 & $2.7964(16)$ & 173 \\
$\mathrm{~N} 4-\mathrm{H} 4 \cdots 2^{\text {viii }}$ & 0.86 & 1.95 & $2.8033(17)$ & 175 \\
$\mathrm{~N} 6-\mathrm{H} 6 \cdots 6^{\text {ix }}$ & 0.86 & 1.95 & $2.8002(17)$ & 172 \\
$\mathrm{O} 8-\mathrm{H} 8 A \cdots 6^{\text {ix }}$ & $0.86(2)$ & $1.92(2)$ & $2.7412(16)$ & $159(2)$ \\
$\mathrm{O} 8-\mathrm{H} 8 B \cdots 5^{\text {vii }}$ & $0.86(2)$ & $1.92(2)$ & $2.7443(16)$ & $160(2)$ \\
$\mathrm{O} 10-\mathrm{H} 10 A \cdots \mathrm{N} 5^{\mathrm{x}}$ & $0.87(2)$ & $2.16(2)$ & $3.0311(19)$ & $177(3)$ \\
$\mathrm{O} 10-\mathrm{H} 10 B \cdots \mathrm{N} 5^{\mathrm{xi}}$ & $0.86(2)$ & $2.18(2)$ & $3.0342(19)$ & $174(3)$ \\
$\mathrm{O} 7-\mathrm{H} 7 A \cdots \mathrm{N} 2^{\mathrm{ii}}$ & $0.88(3)$ & $2.09(3)$ & $2.908(2)$ & $154(2)$ \\
$\mathrm{O} 7-\mathrm{H} 7 B \cdots \mathrm{N} 2^{\text {iii }}$ & $0.88(2)$ & $2.09(2)$ & $2.905(2)$ & $153(2)$ \\
\hline
\end{tabular}

Symmetry codes: (ii) $x, y+1, z$; (iii) $-x+2,-y,-z+2$; (vi) $-x+1,-y,-z+2$; (vii) $x+1, y-1, z$; (viii) $x-1, y+1, z$; (ix) $-x+2,-y+2,-z+1$; (x) $-x+1,-y+2$, $-z+2$; (xi) $x, y-1, z+1$. 